\title{
Spinal Transection Induces Widespread Proliferation of Cells along the Length of the Spinal Cord in a Weakly Electric Fish
}

\author{
Antiño R. Allen ${ }^{\mathrm{a}, \mathrm{b}}$ G. Troy Smith ${ }^{\mathrm{a}-\mathrm{c}}$ \\ ${ }^{a}$ Department of Biology, ${ }^{b}$ Center for the Integrative Study of Animal Behavior, and ${ }^{c}$ Program in Neuroscience, \\ Indiana University, Bloomington, Ind., USA
}

\section{Key Words}

Spinal transection - Cellular proliferation - Electric fish • Apteronotus leptorhynchus

\begin{abstract}
The ability to regenerate spinal cord tissue after tail amputation has been well studied in several species of teleost fish. The present study examined the proliferation and survival of cells following complete spinal cord transection rather than tail amputation in the weakly electric fish Apteronotus leptorhynchus. To quantify cell proliferation along the length of the spinal cord, fish were given a single bromodeoxyuridine (BrdU) injection immediately after spinal transection or sham surgery. Spinal transection significantly increased the density of $\mathrm{BrdU}^{+}$cells along the entire length of the spinal cord at 1 day posttransection (dpt), and most newly generated cells survived up to $14 \mathrm{dpt}$. To examine longer-term survival of the newly proliferated cells, BrdU was injected for 5 days after the surgery, and fish were sacrificed at 14 or $30 \mathrm{dpt}$. Spinal transection significantly increased cell proliferation and/or survival, as indicated by an elevated density of BrdU ${ }^{+}$ cells in the spinal cords of spinally transected compared to sham-operated and intact fish. At $14 \mathrm{dpt}, \mathrm{BrdU}^{+}$cells were abundant at all levels of the spinal cord. By $30 \mathrm{dpt}$, the den-
\end{abstract}

sity of $\mathrm{BrdU}^{+}$cells had decreased at all levels of the spinal cord except at the tip of the tail. Thus, newly generated cells in the caudal-most segment of the spinal cord survived longer than those in more rostral segments. Our findings indicate that spinal cord transection stimulates widespread cellular proliferation; however, there were regional differences in the survival of the newly generated cells.

Copyright $\odot 2012$ S. Karger AG, Basel

\section{Introduction}

Severe spinal cord injuries in adult mammals abolish motor and sensory function. Such injuries result in the formation of scar tissue, which inhibits axonal regeneration in the affected area. The inability to regenerate axons leads to a concomitant loss of neurons caudal to the injury site, resulting in paralysis [Horner et al., 2000]. Unlike mammals, adult teleost fish spontaneously regenerate spinal cord after cord transection or tail amputation [Coggeshall and Youngblood, 1983; Yamada et al., 1995; Becker et al., 1997; Hanna et al., 1998]. Following spinal transection, cells rapidly proliferate, invade the wound and seal over the cut ends to prevent further injury to the central nervous system (CNS) [Chernoff, 1996]. This re-

\section{KARGER}

Fax +4161306 1234

E-Mail karger@karger.ch

www.karger.com
(C) 2012 S. Karger AG, Basel

0006-8977/12/0804-0269\$38.00/0

Accessible online at:

www.karger.com/bbe
Antiño R. Allen

Department of Neurosurgery, San Francisco General Hospital

1001 Potrero Avenue, Building 1, Room 101, Campus Box 0899

San Francisco, CA 94110 (USA)

E-Mail allena1@ @eurosurg.ucsf.edu 
sponse to injury provides an environment that protects axon stumps from degeneration and promotes growth.

The brown ghost knifefish (Apteronotus leptorhynchus) provides a convenient vertebrate system in which to study cellular proliferation and regeneration in the adult CNS. Apteronotid fishes often lose their tails to predators or during aggressive encounters with conspecifics, and the entire tail, including the anal ribbon fin, electric organ, muscle, spinal cord and vertebrae, regenerates after amputation [Anderson and Waxman, 1985]. Injury to the apteronotid tail stimulates proliferation and migration of the ependymal cells close to the injury. The new tissue regenerates within a blastema that is dominated by an ependymal outgrowth at a rate of approximately $1 \mathrm{~mm}$ per week [Anderson and Waxman, 1981]. During regeneration, the basic structural plan is conserved, which allows the new neurons to be incorporated into the electromotor circuit [Anderson and Waxman, 1983b]. There is no known limit to the number of times the tail will regenerate after amputation [Anderson and Waxman, 1985; Sîrbulescu et al., 2009]. Although numerous studies have characterized robust proliferation and regeneration at the tip of the tail after amputation [Anderson and Waxman, 1985; Sîrbulescu et al., 2009], much less is known about spinal regeneration in electric fish after high-level spinal injuries [cf. Schaefer and Zakon, 1997]. The current study addressed three main questions: (1) Do regeneration and cellular proliferation occur after a high-level spinal cord transection?; (2) If so, what is the rostrocaudal distribution of the cells that proliferate in response to spinal cord injury?, and (3) How long do newly proliferated cells persist after spinal injury?

\section{Materials and Methods}

\section{Animals}

Forty brown ghost knifefish (A. leptorhynchus; length 70-170 $\mathrm{mm}$, body mass 11-25 g) were housed individually in 36- or 64-liter tanks. The tanks were maintained on a 12/12-hour light/dark cycle at $26.0-26.4^{\circ} \mathrm{C}, \mathrm{pH} 5.5-6.9$ and conductivity of $200-800$ $\mu \mathrm{S} \cdot \mathrm{cm}^{-1}$. All procedures were performed according to the experimental standards established by the NIH Guide for Care and Use of Laboratory Animals, and the protocols were approved by the Bloomington Institutional Animal Care and Use Committee.

\section{Transection of the Spinal Cord}

Each fish was anesthetized by immersion in 0.075\% 2-phenoxyethanol until the respiratory movements of the operculum became shallow. The anesthetized fish were transferred to an operating chamber where they were artificially ventilated throughout the surgery with freshly oxygenated water. A sterile scalpel was used to make a 2- to 3-mm-long incision along the dorsal stripe at approximately $50 \%$ of the length from the eye to the caudal end of the anal fin. The vertebral arches were removed from 1-2 spinal segments with sterile forceps, and the underlying spinal cord was completely transected. The skin and muscle over the incision site were sutured and sealed with Nexaband veterinary adhesive (Abbott Laboratories, North Chicago, Ill., USA). Additional fish received sham operations in which an incision was made through skin and muscle without transection of the spinal cord. Animals were monitored continuously until they recovered from anesthesia. Following the surgery, the fish were initially unable to move the caudal portion of their tail and anal fin; however, they could swim around their tank with the use of their pectoral fins and the rostral portion of their anal ribbon fin. The fish were monitored daily, and mercurochrome $(0.5 \%)$ or povidone iodine $(10 \%)$ was applied to the incision to prevent infection. Untreated fish were used as nonsurgical controls.

\section{Bromodeoxyuridine Injections}

Bromodeoxyuridine (BrdU) was used to study proliferation of cells in intact and spinally transected animals. BrdU is a nucleotide analogue that competes with endogenous thymidine during the DNA synthesis, or S phase, of the mitotic cycle. Precursor cells dividing in the presence of BrdU incorporate it into their DNA, permanently labeling the newly divided cells [Gratzner, 1982]. In experiment 1 , animals were given a single injection of BrdU (Sigma; $0.2 \mathrm{mg} / \mathrm{g}$ body weight, i.p.) immediately after surgery and sacrificed 1 or 14 days after injection $(n=3-5$ for each survival group and treatment group). In experiment 2 , each fish was injected with $\mathrm{BrdU}(0.2 \mathrm{mg} / \mathrm{g}$ body weight/day, i.p.) daily for 5 days after spinal transection or sham surgery and sacrificed 14 or 30 days after surgery (fig. 1).

\section{Perfusion and Tissue Preparation}

Fish were anesthetized with 2-phenoxyethanol and transcardially perfused with a heparinized Krebs-Henseleit buffer (in mM: $118 \mathrm{NaCl}, 4.7 \mathrm{KCl}, 1.2 \mathrm{MgSO}_{4}, 1.2 \mathrm{KH}_{2} \mathrm{PO}_{4}, 25 \mathrm{NaHCO}_{3}, 2.0$ $\mathrm{CaCl}_{2} ; 2$ units/ml heparin; $\mathrm{pH}$ 7.4) followed by phosphate-buffered $4 \%$ paraformaldehyde ( $\mathrm{pH} 7.4$ ). After perfusion, the tail was removed and divided into four sections as follows: $2 \mathrm{~mm}$ rostral to the transection site (RTS), $2 \mathrm{~mm}$ caudal to the transection site (CTS), at the level of the caudal end of the anal fin (AF) and the tip of the tail (TT). Tail sections were postfixed in $4 \%$ paraformaldehyde $\left(1 \mathrm{~h}\right.$ at $\left.4^{\circ} \mathrm{C}\right)$ and cryoprotected $(24-48 \mathrm{~h}, 20 \%$ sucrose in $0.1 \mathrm{M}$ phosphate buffer, $\mathrm{pH}$ 7.4). The blocked tail segments were embedded in OCT mounting medium (Tissue Tek, Torrance, Calif., USA), cryosectioned at $35 \mu \mathrm{m}$ and mounted directly onto microscope slides (SuperFrost Plus, Fisher, Pittsburgh, Pa., USA).

\section{BrdU Immunohistochemistry}

Each slide was air dried, postfixed for $10 \mathrm{~min}$ in $4 \%$ paraformaldehyde and rinsed in $0.1 \mathrm{M}$ phosphate-buffered saline (PBS; $\mathrm{pH}$ 7.4). The tail sections were treated with $1 \mathrm{~N}$ hydrochloric acid for $30 \mathrm{~min}$ at $37^{\circ} \mathrm{C}$ to denature DNA. The slides were immersed in $0.1 \mathrm{M} \mathrm{Na}_{2} \mathrm{~B}_{4} \mathrm{O}_{7}$ to neutralize the acidic $\mathrm{pH}$, followed by 2 rinses in $\mathrm{PBS}$ for $5 \mathrm{~min}$ each to return the $\mathrm{pH}$ to approximately 7.4. Nonspecific antigen binding was blocked with PBS containing 4\% normal goat serum and $0.25 \%$ Triton X-100 (PBS-TX). Slides were incubated overnight at room temperature with a polyclonal rabbit anti-BrdU antibody (BP40250; Megabase, Lincoln, Nebr., USA) at a final dilution of $1: 10,000$ in $4 \%$ normal goat serum in PBS-TX. 
Sections were incubated with a goat antirabbit Alexa Fluor 488 secondary antibody at a dilution of 1:200 (A-11008; Molecular Probes, Carlsbad, Calif., USA) for $1 \mathrm{~h}$ at room temperature.

To determine the effects of transection on the fate of the newly generated cells in the spinal cord, a subset of sections (1-2 spinal cords from intact and transected fish at the 30-day survival time point) were double labeled for BrdU and the neuronal marker $\mathrm{Hu}$ or glial fibrillary acidic protein (GFAP). These sections were processed for BrdU as above and then rinsed 3 times with PBS, for $5 \mathrm{~min}$ each. The sections were then incubated overnight with either a monoclonal mouse anti-Hu antibody at a dilution of 1:100 (A-21271; Molecular Probes) or monoclonal anti-GFAP antibody at 1:100 (G3893; Sigma). Sections were incubated with a goat antimouse Cy3 secondary antibody at 1:200 (AP124C; Molecular Probes) for $1 \mathrm{~h}$ at room temperature. DNA was stained by incubating sections for $30 \mathrm{~min}$ in a 4',6-diamidino-2-phenylindole solution at 1:1,000 (D21490; Molecular Probes). Slides were coverslipped with Vectashield hard set.

\section{Stereology}

BrdU-labeled cells were counted in transverse sections from four locations along the length of the tail (see above). Total cell number was estimated using the optical fractionator method [Gundersen, 1986; West et al., 1991] implemented with the Stereo Investigator software (Microbrightfield, Inc., Williston, Vt., USA). Contours that encompassed the entire cross-section of the spinal cord in transverse sections were created using a $10 \times / 0.45$ numerical aperture objective, and cells were counted using a $60 \times / 1.40$ numerical aperture objective. The thickness of each section was measured, and $2-\mu \mathrm{m}$ guard zones at the top and the bottom of the section were defined to avoid oversampling. Counting frames were $40 \times 40 \mu \mathrm{m}$ with a dissector height of $18 \mu \mathrm{m}$. Stereo Investigator used a random systematic sampling scheme with a $141 \times 172-\mu \mathrm{m}$ sampling grid laid over each contour. To normalize for variation in the cross-sectional area across individuals or along the length of the spinal cord, we calculated the densitiy of $\mathrm{BrdU}^{+}$neurons in the spinal cord by dividing the number of $\mathrm{BrdU}^{+}$cells estimated by the fractionators in each section by the volume of the spinal cord in that section.

\section{Radial Distribution of $\mathrm{BrdU}^{+}$Cells}

The $\mathrm{x}$-y coordinates (in micrometers with the central canal as the origin) of every BrdU ${ }^{+}$cell were exported from the Stereo Investigator software. The distance of cells from the central canal was calculated as $d=\sqrt{ }\left(x^{2}+y^{2}\right)$. The distance of cells from the central canal was then normalized to the average distance from the central canal to the edge of the spinal cord to correct for variation in the diameter of the spinal cord between individuals and across different rostrocaudal levels.

\section{Statistical Analyses}

The effects of position, survival time and treatment on the density of $\mathrm{BrdU}^{+}$cells were evaluated with repeated-measures analyses of variance (ANOVAs). When significant main effects or interactions were found, differences between levels within factors were determined with Fisher's Protected Least Significant Difference (PLSD) post hoc test in Statistica (StatSoft Inc., Tulsa, Okla., USA). The cross-sectional area of spinal cords was compared across treatments with one-way ANOVAs, and the relationship between cross-sectional area and the density of $\mathrm{BrdU}^{+}$cells was

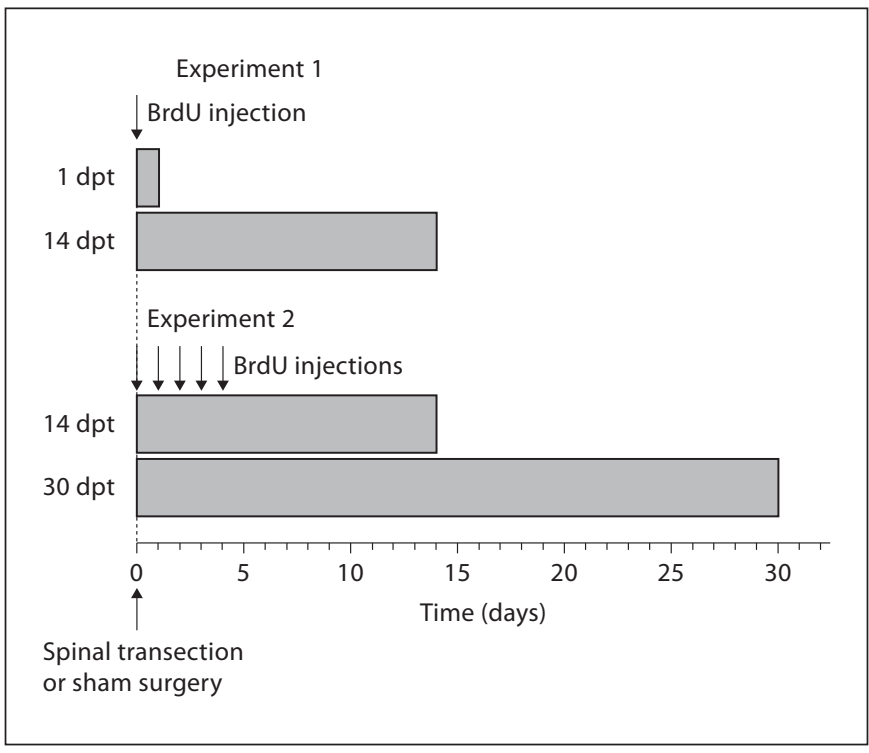

Fig. 1. Schematic diagram showing the experimental design. Experiment 1: immediately after spinal transection or sham surgery, fish were injected with BrdU and then sacrificed at 1 or $14 \mathrm{dpt}$. Experiment 2: BrdU injections were given once a day for 5 days after surgery, and fish were sacrificed at 14 or $30 \mathrm{dpt}$.

explored using a general linear model, with cross-sectional area as a continuous factor and treatment as a discrete factor. Significance was defined by an $\alpha$ value of 0.05 .

\section{Results}

\section{Constitutive Cell Proliferation and Short-Term \\ Proliferative Response to Spinal Transection}

To examine the immediate proliferative response to the transection and to study the distribution of the proliferating $\left(\mathrm{BrdU}^{+}\right)$cells both along the rostrocaudal axis and radially from the central canal, we injected fish with a single dose of BrdU immediately after transection and sacrificed them at 1 or 14 days posttransection (dpt; experiment 1; fig. 1). Low rates of cellular proliferation, as indicated by the presence of BrdU-containing cells, occurred in the intact uninjured spinal cords. BrdU ${ }^{+}$cells were present at all levels of the spinal cord in sham-operated fish at 1 and 14 days postinjection (dpi). The density of $\mathrm{BrdU}^{+}$cells did not differ significantly between 1 and 14 dpi in sham-operated fish (fig. 2; effect of survival time: $\left.F_{1,6}=0.011, p=0.91\right)$. However, the density of cell proliferation was more robust at the TT than more rostrally in the sham-operated fish (fig. 3; effect of position: $\left.\mathrm{F}_{3,18}=41.4, \mathrm{p}<0.001\right)$. 


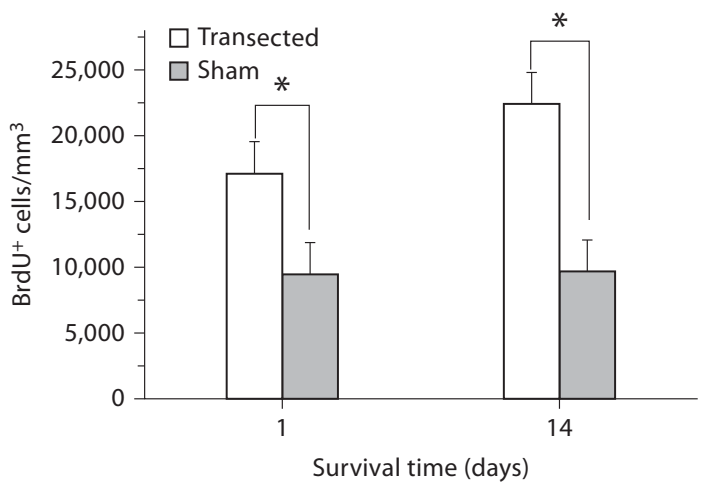

Fig. 2. Density of BrdU ${ }^{+}$cells (mean \pm SEM) in spinally transected and sham-operated fish given a single injection of BrdU. Fish were sacrificed 1 or 14 days after surgery. Spinal transection significantly increased cell proliferation and/or survival as indicated by an elevated density of $\mathrm{BrdU}^{+}$cells in the spinal cords of spinally transected compared to sham-operated fish. ${ }^{*} \mathrm{p}<0.05$ (ANOVA).

Table 1. Number of BrdU ${ }^{+}$cells (mean \pm SEM) in experiment 1 (single BrdU injection)

\begin{tabular}{lrrll}
\hline & \multicolumn{1}{l}{ RTS } & \multicolumn{1}{l}{ CTS } & AF & TT \\
\hline 1-day survival & & & & \\
$\quad$ Sham & $810 \pm 123$ & $910 \pm 296$ & $215 \pm 16$ & $244 \pm 67$ \\
$\quad$ Transected $^{1}$ & $1,833 \pm 381$ & $2,092 \pm 319$ & $551 \pm 102$ & $459 \pm 78$ \\
14-day survival $_{\text {Sham }}$ & $1,625 \pm 467$ & $1,497 \pm 442$ & $402 \pm 99$ & $539 \pm 73$ \\
Transected $^{2}$ & $2,567 \pm 726$ & $2,731 \pm 646$ & $947 \pm 159$ & $633 \pm 61$ \\
\hline
\end{tabular}

${ }^{1}$ Transected $>$ sham (main effect of treatment: $\mathrm{F}_{1,6}=9.66, \mathrm{p}=$ $0.02)$.

2 Transected not significantly different from sham (main effect of treatment: $F_{1,7}=2.67, \mathrm{p}=0.15$ ).

Spinal cord transection significantly increased cell proliferation. Transected cords had nearly twice as many $\mathrm{BrdU}^{+}$cells as sham-operated fish 1 day after surgery (table $1 ; \mathrm{F}_{1,6}=9.66, \mathrm{p}=0.02$ ). The number of $\mathrm{BrdU}^{+}$cells was not significantly higher in transected than in sham-operated fish in the 14-day survival groups $\left(\mathrm{F}_{1,7}=2.67, \mathrm{p}=\right.$ $0.15)$. The cross-sectional area of the spinal cords did not differ significantly between the transected and sham- operated fish that received single BrdU injections (online suppl. table 1; for all online suppl. material, see www. karger.com/doi/10.1159/000342485; 1-day survival group: $\mathrm{F}_{1,7}=0.9, \mathrm{p}=0.37$; 14-day survival group: $\mathrm{F}_{1,7}=1.9, \mathrm{p}=$ 0.21 ). Nevertheless, the area of the spinal cord, which varied both with fish size and with position along the spinal cord, could influence the number of BrdU ${ }^{+}$cells in each section. In subsequent analyses, we therefore normalized for spinal cord volume by measuring the density of $\mathrm{BrdU}^{+}$ cells. Transected spinal cords had nearly double the density of $\mathrm{BrdU}^{+}$cells compared to sham-operated spinal cords at $1 \mathrm{dpt}$ (fig. 2; effect of treatment: $\mathrm{F}_{1,6}=6.46, \mathrm{p}<$ 0.05). These cells were sustained up to at least $14 \mathrm{dpt}$. Transected spinal cords also had more than twice the density of $\mathrm{BrdU}^{+}$cells compared to sham-operated spinal cords at $14 \mathrm{dpt}$ (fig. 2 ; effect of treatment: $\mathrm{F}_{1,6}=11.16, \mathrm{p}=$ $0.015)$. In addition, the density of $\mathrm{BrdU}^{+}$cells did not differ significantly between 1 and $14 \mathrm{dpt}$ in transected fish (fig. 2; effect of survival time: $\mathrm{F}_{1,6}=1.42, \mathrm{p}=0.27$ ).

The immediate cellular proliferation induced by spinal cord transection occurred along the entire length of the spinal cord but was more robust in the caudal portion of the spinal cord. At $1 \mathrm{dpt}$, a significantly greater density of $\mathrm{BrdU}^{+}$cells was present at the AF than immediately rostral and caudal to the transection site (RTS and CTS; fig. 3a; effect of position: $\left.\mathrm{F}_{3,18}=5.61, \mathrm{p}<0.05\right)$. At $14 \mathrm{dpt}$, there was a greater density of $\mathrm{BrdU}^{+}$cells at both caudal levels (AF and TT) of the spinal cord than at the more rostral levels (RTS and CTS; fig. 3b; effect of position: $\left.\mathrm{F}_{3,18}=41.436, \mathrm{p}<0.001\right)$.

\section{Radial Distribution of Newly Proliferated Cells}

The ependymal cells that line the central canal of the spinal cord play a significant role in regeneration after injury in anamniotic vertebrates. After amputation and transection, ependymal cells rapidly proliferate, migrate and differentiate to regenerate the cord [Chernoff, 1996]. To examine whether the newly proliferated cells originated in the central canal, the mean distance of each $\mathrm{BrdU}^{+}$cell from the central canal was measured using the central canal as the origin. There was no significant effect of transection or survival time on the medial-lateral and dorso-ventral distribution of cells. At $1 \mathrm{dpt}, \mathrm{BrdU}^{+}$cells were evenly dispersed throughout the spinal cord. The average distance of $\mathrm{BrdU}^{+}$cells was more than half the distance from the central canal to the edge of the spinal cord (fig. 4), and many cells were located near the edge of the spinal cord (fig. 5). It is unlikely that BrdU-labeled cells could migrate from the central canal to locations throughout the spinal cord in as little as $24 \mathrm{~h}$. Thus, the 


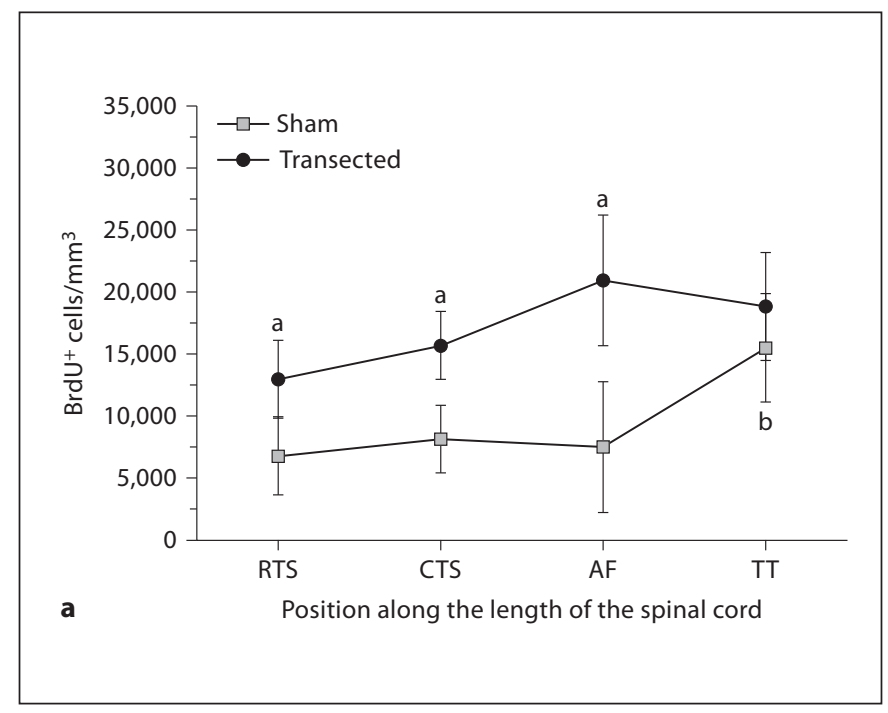

Fig. 3. Density of BrdU ${ }^{+}$cells in spinally transected and shamoperated fish as a function of position, treatment and survival time after a single BrdU injection on the day of surgery. a At $1 \mathrm{dpt}$, significantly more $\mathrm{BrdU}^{+}$cells were present in transected than in sham-operated fish at every position of the spinal cord except the TT. In sham-operated fish, significantly more BrdU ${ }^{+}$cells were present at the TT than at other rostrocaudal levels. b At $14 \mathrm{dpt}$, significantly more $\mathrm{BrdU}^{+}$cells were present in transected than in

radial distribution of $\mathrm{BrdU}^{+}$cells suggests that a source of progenitor cells other than ependymal cells may also contribute to the production of new cells in the apteronotid spinal cord.

\section{Cell Proliferation and Survival of Cells after Spinal Cord Transection}

To examine longer-term effects of spinal transection on cell proliferation, BrdU was injected for 5 days after spinal cord transection or sham surgery. Unoperated control fish were also injected with BrdU for 5 days. In unoperated control fish, BrdU ${ }^{+}$cells were observed throughout the spinal cord at 14 and 30 dpi (fig. 5a, d). At 14 and 30 dpi, the density of BrdU ${ }^{+}$cells did not differ significantly between sham-transected and unoperated fish (fig. 5a, b, d, e, 6).

During the first 5 days after spinal transection, proliferation increased uniformly along the entire length of the spinal cord. The number of $\mathrm{BrdU}^{+}$cells was 5-10 times greater in transected than in sham-treated or unoperated spinal cords in both the 14- and 30-day survival groups (table 2). The cross-sectional area of the spinal cord was significantly greater in transected fish than in unoperated



sham-operated fish along the entire length of the spinal cord. In transected fish, more BrdU ${ }^{+}$cells were present at AF and TT than at RTS and CTS. As in the 1-day survival fish, more BrdU ${ }^{+}$cells were present at the TT than at other positions in the sham-operated fish. ${ }^{\mathrm{a}} \mathrm{p}<0.05$ vs. sham (PLSD); ${ }^{\mathrm{b}} \mathrm{p}<0.05$ vs. other positions in sham-operated fish (PLSD); ${ }^{\mathrm{c}} \mathrm{p}<0.05$ vs. RTS and CTS in transected fish (PLSD).

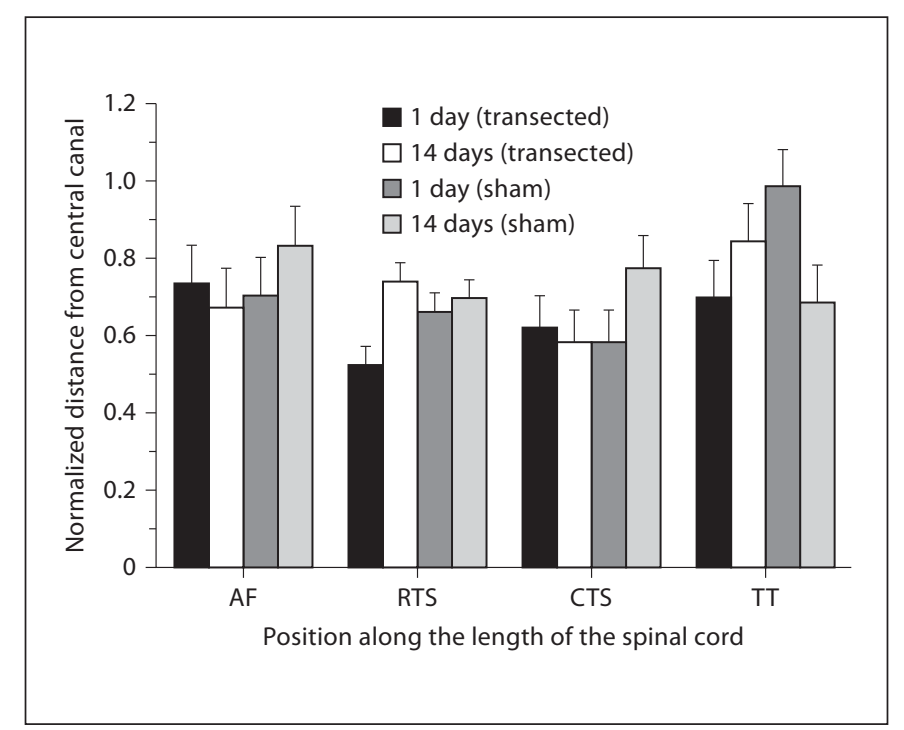

Fig. 4. Relative distance (mean \pm SEM) of $\mathrm{BrdU}^{+}$cells from the central canal as a function of the rostrocaudal position along the tail. The y-axis represents the distance of cells from the central canal normalized to the average distance from the central canal to the edge of the spinal cord in each section. Transection did not affect the radial distribution of $\mathrm{BrdU}^{+}$cells. BrdU ${ }^{+}$cells were evenly distributed throughout the spinal cord at each time period sampled. 

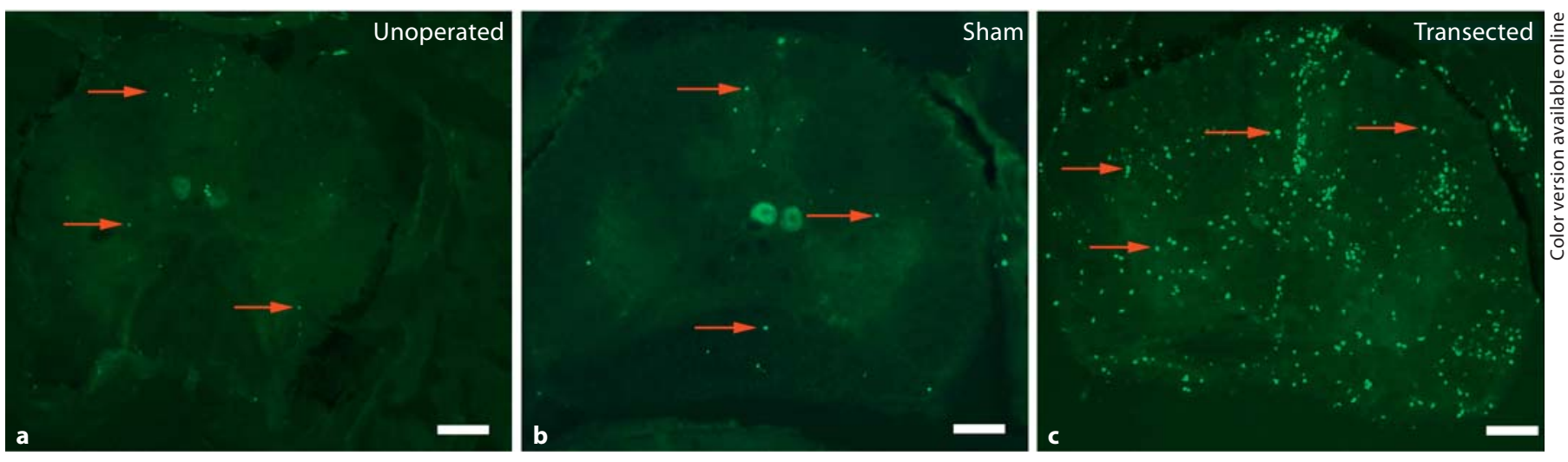

$30 \mathrm{dpt}$
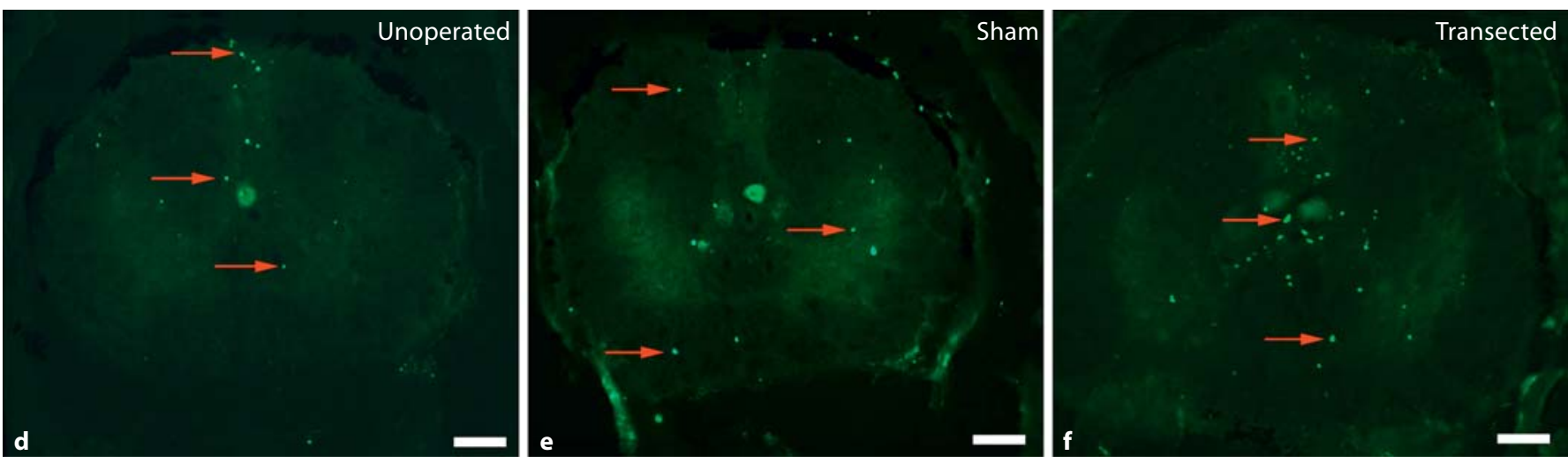

Fig. 5. Representative sections of the spinal cord immunohistochemically labeled for BrdU. These spinal cord sections were from the $\mathrm{AF}$ and were taken from fish injected with BrdU for 5 days after no treatment (a, d), sham surgery $(\mathbf{b}, \mathbf{e})$ or spinal transection $(\mathbf{c}, \mathbf{f})$ and sacrificed $14(\mathbf{a}-\mathbf{c})$ or $30(\mathbf{d}-\mathbf{f})$ days later. Dorsal is up.
$\mathrm{BrdU}^{+}$cells (arrows) were present in unoperated, sham-operated and spinally transected fish. More $\mathrm{BrdU}^{+}$cells were present in spinal cords of spinally transected fish than in control groups at both survival times. By $30 \mathrm{dpt}$, the density of $\mathrm{BrdU}^{+}$cells had decreased relative to $14 \mathrm{dpt}$. Scale bars $=80 \mu \mathrm{m}$. and/or sham-treated fish, most likely because the transected fish in this experiment were larger than the fish in the control groups (online suppl. table 1; 14-day survival group: $\mathrm{F}_{2,10}=33.2, \mathrm{p}<0.001 ; 30$-day survival group: $\mathrm{F}_{2,10}=9.3, \mathrm{p}<0.01$ ). As in experiment 1 , we therefore normalized for variation in the cross-sectional area of the spinal cord across individuals and positions along the length of the spinal cord by measuring cell densities. The density of $\mathrm{BrdU}^{+}$cells in the spinal cord was 3 times greater in spinally transected than in control fish (fig. 5, 6; effect of treatment: $\mathrm{F}_{2,9}=19.80, \mathrm{p}<0.001$; PLSD for transected vs. controls: $\mathrm{p}<0.001$ ). In 30 -day survival fish, more than half of the $\mathrm{BrdU}^{+}$cells persisted in all three treatment groups (fig. 5, 6). However, spinally transected fish still had more than twice the density of $\mathrm{BrdU}^{+}$cells in the spinal cord as in sham-operated and unoperated control fish (fig. 6; effect of treatment: $\mathrm{F}_{2,9}=12.07, \mathrm{p}<0.05$; PLSD for transected vs. controls: $\mathrm{p}<0.001)$. The density of $\mathrm{BrdU}^{+}$ cells tended to be lower in the spinal cords of 30-dpt fish than in those of 14-dpt fish, but this difference did not reach statistical significance (fig. 6; effect of survival time: $\left.\mathrm{F}_{1,6}=4.60, \mathrm{p}=0.07\right)$. After factoring out the effects of treatment, the cross-sectional area of the spinal cord did not significantly affect $\mathrm{BrdU}^{+}$cell density in either the single-injection or 5-injection fish (online suppl. fig. 1; general linear model: single injection, $\mathrm{F}_{1,15}=0.01, \mathrm{p}=0.91 ; 5$ injections, $\mathrm{F}_{1,22}=0.65, \mathrm{p}=0.43$ ), which suggests that the effects of spinal transection on $\mathrm{BrdU}^{+}$cell density did not result from differences in the size of the fish.

The survival of newly proliferated cells varied with the position along the length of the spinal cord. At $14 \mathrm{dpt}$, the density of $\mathrm{BrdU}^{+}$cells was greater at every rostrocaudal 
Table 2. Number of $\mathrm{BrdU}^{+}$cells (mean \pm SEM) in fish injected on days 1-5

\begin{tabular}{lcccc}
\hline Treatment & RTS & CTS & AF & TT \\
\hline 14-day survival & & & & \\
$\quad$ Unoperated & $1,075 \pm 165$ & $940 \pm 161$ & $363 \pm 176$ & $278 \pm 57$ \\
Sham & $1,915 \pm 552$ & $1,522 \pm 416$ & $546 \pm 74$ & $374 \pm 92$ \\
$\quad$ Transected & $13,567 \pm 127$ & $10,125 \pm 1,009$ & $3,394 \pm 477$ & $2,548 \pm 694$ \\
30-day survival & & & & \\
$\quad$ Unoperated $_{\text {Sham }}$ & $918 \pm 220$ & $907 \pm 207$ & $290 \pm 101.7$ & $225 \pm 56$ \\
Transected $^{2}$ & $2,206 \pm 611$ & $1,516 \pm 528$ & $293 \pm 48.25$ & $254 \pm 40$ \\
\hline
\end{tabular}

${ }^{1}$ Transected $>$ sham and unoperated (main effect of treatment: $\left.\mathrm{F}_{2,10}=52.8, \mathrm{p}<0.001\right) .{ }^{2}$ Transected $>$ sham and unoperated $(\mathrm{main}$ effect of treatment: $\left.\mathrm{F}_{2,10}=27.2, \mathrm{p}<0.001\right)$.

level in the spinally transected fish than in either of the control groups (fig. 7a; effect of treatment: $F_{2,9}=19.80$, $\mathrm{p}<0.001$; PLSD for transected vs. controls: $\mathrm{p}<0.001$ ). The density of $\mathrm{BrdU}^{+}$cells was similar along the entire length of the spinal cord in the 14-dpt fish (fig. 7a, c; effect of position: $\mathrm{F}_{3,18}=3.59, \mathrm{p}=0.53$ ). At $30 \mathrm{dpt}$, spinally transected fish continued to have a greater density of $\mathrm{BrdU}^{+}$cells at every rostrocaudal level of the spinal cord (fig. 7b). However, by $30 \mathrm{dpt}$, the density of BrdU ${ }^{+}$cells at the TT was nearly twice that in more rostral parts of the spinal cord (fig. 7b, c; effect of position: $\mathrm{F}_{3,18}=5.58, \mathrm{p}<0.05$ ).

Sections from a subset of spinal cords from the 30-day survival group (1-2 spinal cords from each treatment group) were double labeled with BrdU and neuronal $(\mathrm{HuC} / \mathrm{D})$ or glial (GFAP) markers. None of the BrdU-labeled cells in these sections colocalized with $\mathrm{HuC} / \mathrm{D}$, which indicates that most of the newly generated cells did not differentiate into neurons. In many instances, BrdUlabeled nuclei were located in the area of GFAP immunoreactivity. The glial fibers were dense with little cytoplasm; therefore, we could not determine whether the BrdU-labeled nuclei belonged to the GFAP immunoreactivity.

\section{Discussion}

This study was designed to (1) quantify cellular proliferation in the intact apteronotid spinal cord and (2) characterize the effect of high-level spinal cord injury (transection) on cellular proliferation and survival. Our data provide evidence of a proliferative population of cells at several levels along the spinal cord in intact individuals. The current work also shows that spinal cord transection significantly increases proliferation and/or survival of

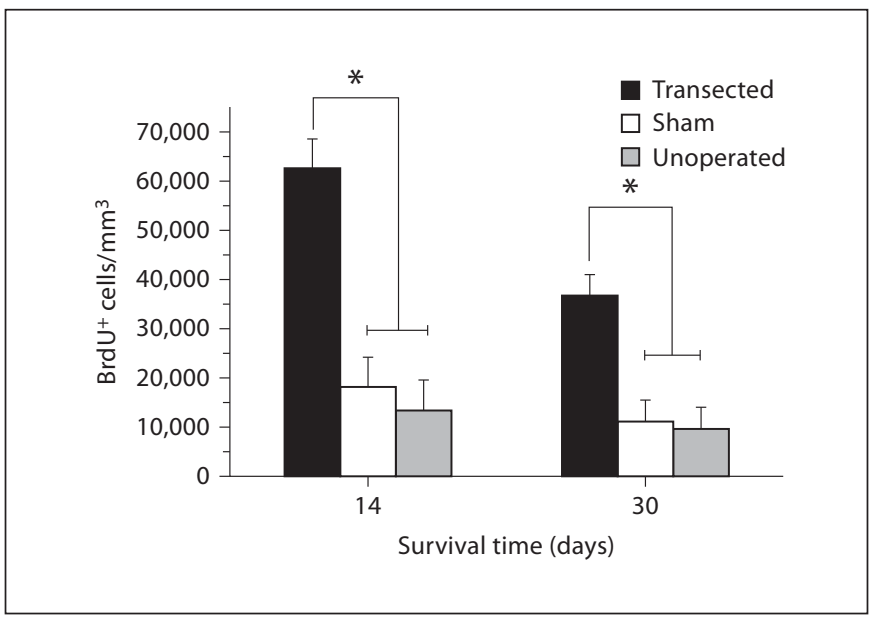

Fig. 6. Density of BrdU' cells (mean \pm SEM) in spinally transected and control fish injected with BrdU for 5 days. Fish were sacrificed 14 or 30 days later. Spinal transection significantly increased cell proliferation and/or survival as indicated by an elevated density of $\mathrm{BrdU}^{+}$cells in the spinal cords of spinally transected compared to sham-operated and unoperated fish. ${ }^{*} \mathrm{p}<$ 0.05 (Fisher's PLSD).

newly generated cells. Transection led to widespread upregulation of cellular proliferation along the entire length of the spinal cord. In addition, proliferating cells survived longer in the most caudal spinal cord segments than in more rostral regions.

\section{Cellular Proliferation in the Intact Spinal Cord}

Consistent with a recent report [Sîrbulescu et al., 2009], this study found $\mathrm{BrdU}^{+}$cells in the most caudal segment of the intact apteronotid spinal cord. In addition, 




Fig. 7. Effects of survival time and position on the density of BrdU cells (mean \pm SEM). Density of BrdU ${ }^{+}$cells in transected, shamoperated and unoperated fish injected with BrdU for 5 days after treatment. a Spinal transection significantly increased the density of $\mathrm{BrdU}^{+}$cells uniformly along the entire length of the spinal cord at $14 \mathrm{dpt}$. b Transected fish continued to have a greater density of $\mathrm{BrdU}^{+}$cells than control fish along the entire length of the spinal cord at $30 \mathrm{dpt}$. A higher density of $\mathrm{BrdU}^{+}$cells was present at the TT than at other rostrocaudal levels, indicating that proliferated cells survived longer in the caudal-most spinal cord than in more rostral regions. c Density of BrdU ${ }^{+}$cells (mean \pm SEM) in transected fish as a function of position and survival time. The density of $\mathrm{BrdU}^{+}$cells decreased at rostral levels of the cord (RTS, CTS, AF) but not at the TT between 14 and $30 \mathrm{dpt}^{\mathrm{a}}{ }^{\mathrm{a}} \mathrm{p}<0.05 \mathrm{vs}$. controls (ANOVA, Fisher's PLSD); ${ }^{\mathrm{b}} \mathrm{p}<0.05$ vs. other positions in transected fish (ANOVA, Fisher's PLSD); ${ }^{\mathrm{c}} \mathrm{p}<0.001$ vs. $30 \mathrm{dpt}$ (ANOVA); ${ }^{\mathrm{d}} \mathrm{p}<0.001$ vs. other positions at $30 \mathrm{dpt}$ (ANOVA, PLSD).

our data revealed that $\mathrm{BrdU}^{+}$cells were dispersed at all levels of the spinal cord, suggesting that continuous proliferation of cells occurs throughout the spinal cord. The density of BrdU ${ }^{+}$cells in the spinal cord did not differ between sham-operated and unoperated fish. The density of cells in sham-operated and unoperated spinal cords was significantly lower than that in transected fish. This suggests that an incision made through skin and muscle without transection of the spinal cord did not significantly increase cell proliferation, but that the spinal transection did increase proliferation. Although the spinal cord was exposed in the sham-operated controls, the meninges were left intact, and damage to spinal membranes as well as spinal tissues could also have contributed to the effects of transection.
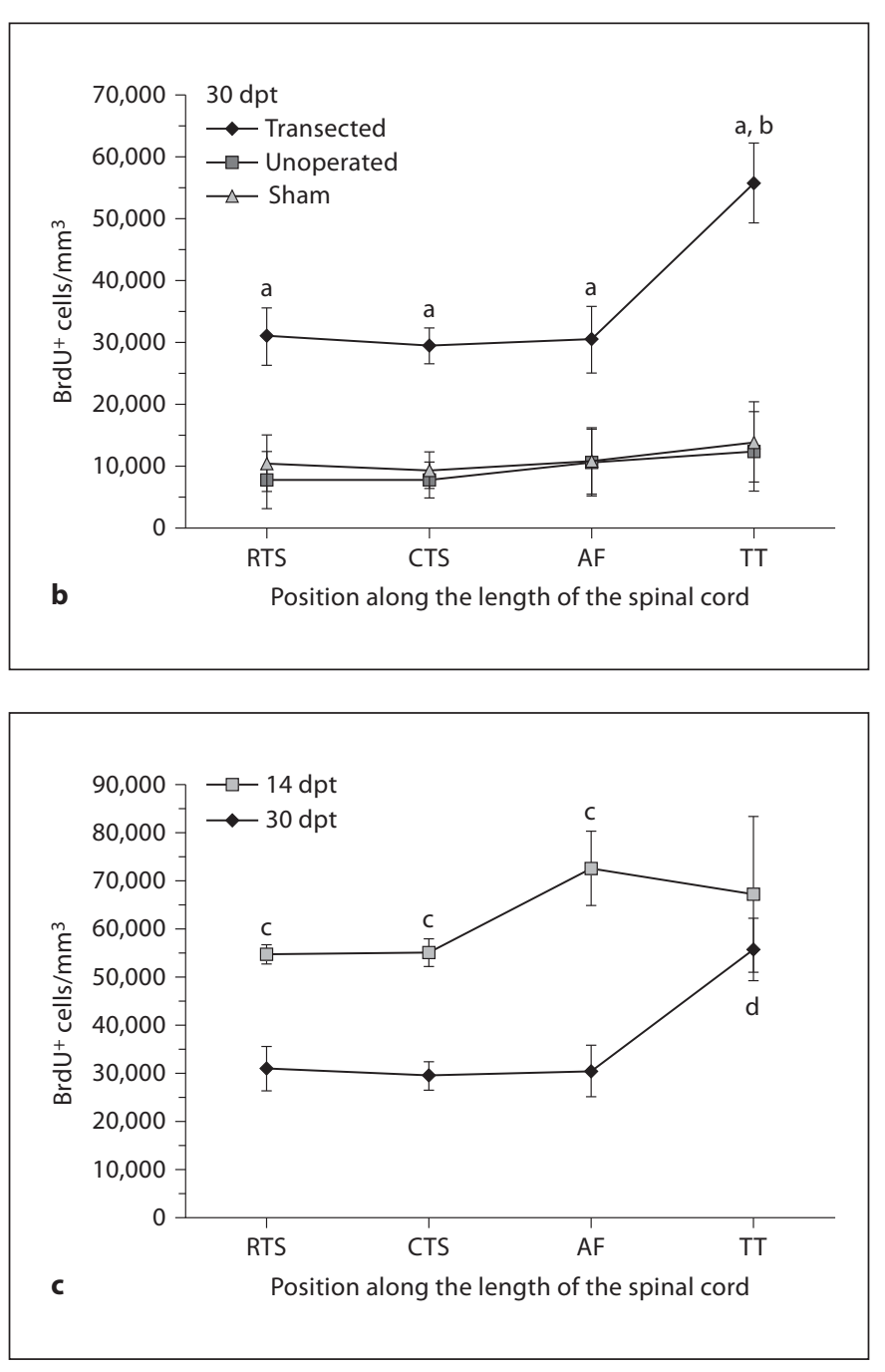

$\mathrm{BrdU}^{+}$cells were present at all sampled levels of the spinal cord in control fish at 1 and 14 dpi. However, a greater density of $\mathrm{BrdU}^{+}$cells was present at the TT than at other rostrocaudal levels. Previous work in a closely related species, Apteronotus albifrons, demonstrated that ependymal cells that surround the central canal at the TT are continuously proliferative [Anderson and Waxman, 1983a; Anderson and Waxman, 1985]. New motor neurons and muscle fibers are continuously added to the caudal-most segment of the tail. The morphological structure of the spinal cord undergoes a gradual transition from a mature pattern more rostrally to a single-cell proliferative ependymal layer at the caudal end of the cord. The ependymal cells that line the central canal of the apteronotid spinal cord are neural stem cells. The cells located at the TT undergo continual proliferation and neu- 
ronal and glial differentiation spanning the life of the animal [Sîrbulescu et al., 2009]. Our results suggest that low levels of proliferation also occur in the rostral spinal cord, although new cells at more rostral levels may not differentiate into neurons.

\section{Effects of Spinal Transection on Proliferation}

A novel finding in this study was that high-level spinal cord injury triggered cellular proliferation along the entire length of the spinal cord, including areas both rostral and caudal to the transection site and at the TT, several centimeters from the injury site. This suggests that the proliferative response in Apteronotus is not simply a local response at the site of injury, but rather represents a global response of the entire spinal cord. This global response may be related to the reorganization of spinal circuits that occurs after transection. For example, descending axons degenerate and regenerate after transection in A. leptorhynchus [Schaefer and Zakon, 1997], and the newly generated cells in the spinal cord may contribute to that process.

The distribution of $\mathrm{BrdU}^{+}$cells in fish injected only on the first day after transection (experiment 1) differed from that in fish that received daily injections for 5 days after transection (experiment 2). In the single-injection fish that survived 14 days after transection, a greater density of BrdU ${ }^{+}$cells was present at the AF and TT than at more rostral levels of the spinal cord. In the 14-dpt fish that received BrdU for 5 days after transection, BrdU ${ }^{+}$ cells were uniformly dispersed along the entire length of the spinal cord. The higher density of $\mathrm{BrdU}^{+}$cells in the caudal relative to the rostral spinal cord at $14 \mathrm{dpt}$ in the single-injection fish, but not in the 5-injection group, suggests that the timing of cell proliferation after injury differs at rostral versus caudal levels of the spinal cord. Although spinal cord transection eventually upregulates cell proliferation along the entire length of the spinal cord, the initial (day 1) proliferation is more robust at the TT than at more rostral levels of the cord. By 2-5 dpt, proliferation is more uniformly distributed along the length of the cord. Because the TT is continuously growing, and there is a larger population of proliferative cells at the TT in intact fish, the TT might be able to upregulate proliferation more rapidly in response to injury than more rostral parts of the spinal cord.

\section{Survival of Newly Proliferated Cells}

To assess longer-term survival of cells newly generated in response to the injury, we compared the number of BrdU-labeled cells in fish sacrificed at $30 \mathrm{dpt}$ with that in fish sacrificed at $14 \mathrm{dpt}$ (both groups having received BrdU injections in the 5 days after transection). Injury significantly increased proliferation and/or survival of cells in the spinal cords of spinally transected compared to sham-operated fish (fig. 6). At $14 \mathrm{dpt}$, the density of $\mathrm{BrdU}^{+}$cells at the AF and TT was comparable to $\mathrm{BrdU}^{+}$ cell counts near the lesion (fig. 7).

At most levels of the spinal cord (RTS, CTS, AF), approximately $50 \%$ fewer $\mathrm{BrdU}^{+}$cells were present at $30 \mathrm{dpt}$ than at $14 \mathrm{dpt}$. The density of $\mathrm{BrdU}^{+}$cells decreased at all levels of the spinal cord except the TT between 14 and 30 dpt. The decrease in BrdU cell density at the rostral levels of the cord between 14 and $30 \mathrm{dpt}$ suggests that many of the cells that were born in response to injury in the rostral cord were lost between 14 and $30 \mathrm{dpt}$. In contrast, the stability of $\mathrm{BrdU}^{+}$cell density between 14 and $30 \mathrm{dpt}$ at the TT suggests that more newly proliferated cells at the caudal end of the spinal cord persisted. This result may reflect different properties of newly generated cells in mature portions of the spinal cord compared to those in the caudal portions of the cord, which are still growing. It is possible that cells in the less mature spinal cord at the TT could be more primed for the development of new spinal cord tissue, as opposed to cells participating in a more transient injury response in the more rostral portions of the cord [Anderson and Waxman, 1983b]. Additionally, differences between the TT and the rostral spinal cord with regard to the survival of proliferative cells could be linked to the ability of apteronotids to regenerate their tails after injury [Anderson and Waxman, 1983b; Sîrbulescu et al., 2009].

An alternative explanation might be that differences in cell proliferation and survival at different rostrocaudal levels are related to the rostrocaudal progression of reafferentiation by descending inputs. Schaefer [1997] characterized the degeneration and regrowth of axons following high-level spinal transection in Apteronotus. Between 1 and $5 \mathrm{dpt}$, the relay axons caudal to the transection degenerate. At $90 \mathrm{dpt}$, relay axons are present caudal to the lesion, and the electric organ has begun to regenerate. In the present study, the density of newly generated cells had decreased in the rostral portions of the cord by $30 \mathrm{dpt}$. By $30 \mathrm{dpt}$, the density of newly generated cells had decreased at every position except the caudal-most segments of the spinal cord. It is possible that the regeneration of the electromotor circuit and axonal regeneration occurring more rostrally might trigger the death of some of the newly generated cells. Since axonal regeneration is delayed in the more caudal levels of the spinal cord, the newly generated cells at the TT may survive longer. 
Table 3. Comparison of cellular proliferation in the intact adult spinal cord

\begin{tabular}{llll}
\hline Species & $\begin{array}{l}\text { Cell pro- } \\
\text { liferation }\end{array}$ & $\begin{array}{l}\text { Neuro- } \\
\text { genesis }\end{array}$ & $\begin{array}{l}\text { Glio- } \\
\text { genesis }\end{array}$ \\
\hline Lamprey $^{1}$ (Petromyzon marinus) & + & - & + \\
Zebrafish $^{2}$ (Danio rerio) & + & - & + \\
Goldfish $^{3}$ (Carassius auratus) & + & + & + \\
Brown ghost knifefish (A. leptorhynchus) $^{\text {Caudal tip of spinal cord }}$ & + & + & \\
Rest of spinal cord $^{5,6}$ & + & $-?$ & + \\
\hline
\end{tabular}

$+=$ Proliferation present; $-=$ proliferation absent; $?=$ proliferation not measured.

${ }^{1}$ Vidal Pizarro et al. [2004]; ${ }^{2}$ Reimer et al. [2008]; ${ }^{3}$ Takeda et al. [2008]; ${ }^{4}$ Sîrbulescu et al. [2009]; ${ }^{5}$ Schaefer and Zakon [1997]; ${ }^{6}$ present study.

New cells in the rostral cord might also represent an early phase of cellular inflammation involving macrophages/microglia. Macrophages/microglia migrate to damaged areas of the CNS and engulf myelin debris and apoptotic cells [Gehrmann and Banati, 1995; Mallat et al., 2005]. Spinal cord transection in Apteronotus removes input from the medullary pacemaker nucleus that controls the electromotor neurons. At 3-5 dpt, axons caudal to the lesion began to disintegrate, leaving the debris of degenerating fibers [Schaefer, 1997]. Our data show that cellular proliferation is uniformly upregulated along the length of the spinal cord during the 5 days after injury. One possible explanation for the increase in cell proliferation along the entire length of the spinal cord observed at $14 \mathrm{dpt}$ is that some of the $\mathrm{BrdU}^{+}$cells represent a population of inflammatory cells that play a role in removing the debris of apoptotic cells and degenerating axons after injury [Popovich et al., 2002]. If the $\mathrm{BrdU}^{+}$cells generated immediately after the injury are macrophages/microglia involved in the degeneration of relay axons, these cells may die or migrate out of the spinal cord once descending axons begin to regrow.

\section{Cross-Species Comparisons of Injury-Induced Cell}

Proliferation in the Spinal Cord

Low levels of cellular proliferation have been found throughout the spinal cord in most fish species that have been studied (table 3). However, these studies have reported variation in the survival and phenotypes of these cells. In lampreys (Petromyzon marinus) and zebrafish (Danio rerio), cells born in the intact spinal cord in mature fish only develop a glial phenotype [Vidal Pizarro et al., 2004; Reimer et al., 2008]. In adult goldfish (Carassius auratus), new cells differentiate into both glia and neurons throughout the spinal cord [Takeda et al., 2008]. In apteronotids, the proliferating cells in the caudal-most spinal cord continuously generate new motor neurons and glia [Anderson and Waxman, 1985; Sîrbulescu et al., 2009]. We did not find cells doubly labeled with BrdU and the neuronal marker $\mathrm{Hu}$ in more rostral portions of the spinal cord in A. leptorhynchus, which suggests that the differentiation of new cells into neurons and glia might be limited to the TT as it grows or regenerates following amputation. However, our interpretations are limited by the fact that we only had doubly labeled tissue from a few animals. It is thus possible that we might not have observed new neurons if they were generated at extremely low rates.

Spinal cord injury (transection or amputation) upregulates cell proliferation in all fish that have been studied (table 4). A novel finding in this study was that high-level spinal cord injury triggered global cellular proliferation along the entire length of the spinal cord, both near and distant from the injury. In contrast, Reimer et al. [2008] found that spinal cord transection in zebrafish only increases cellular proliferation 3-4 $\mathrm{mm}$ from the lesion site. Studies of cell proliferation after spinal transection in other fish species only examined proliferation at the epicenter of the lesion [Dervan and Roberts, 2003; Takeda et al., 2008], so it is unclear whether transection upregulates proliferation throughout the spinal cord in most fish.

Numerous studies have examined the proliferation and differentiation of new cells in the spinal cord after tail amputation in apteronotid fish (table 4). As in the present study of spinal transection, amputation induces robust cell proliferation at the TT [Sîrbulescu et al., 2009]. It is not known whether amputation, like transection, also induces proliferation in more rostral portions of the spinal cord. In contrast to our finding of little differentiation of new cells into neurons after spinal transection, many (approx. $25 \%$ ) of the newly born $\mathrm{BrdU}^{+}$cells generated in response to tail amputation express the neuronal marker HuC/D [Sîrbulescu et al., 2009]. Thus, although spinal transection and tail amputation both induce robust increases in cell proliferation, cellular differentiation and potentially the function of upregulated cellular proliferation differ in response to the two injuries. The response to tail amputation is likely to be related to selection for regeneration of the tail after injury. Apteronotid fish often lose their tails to predators or during aggressive encounters. Tail amputation reduces electric organ dis- 
Table 4. Comparison of cellular proliferation after spinal cord injury

\begin{tabular}{|c|c|c|c|c|c|c|}
\hline Species & Injury & $\begin{array}{l}\text { BrdU injec- } \\
\text { tion, dpt }\end{array}$ & Cell proliferation & $\begin{array}{l}\text { Neuro- } \\
\text { genesis }\end{array}$ & $\begin{array}{l}\text { Glio- } \\
\text { genesis }\end{array}$ & Microglia \\
\hline European eel $^{1}$ (Anguilla anguilla) & transection & 0 & $\uparrow$ near transection & + & + & + \\
\hline Goldfish $^{3}$ (Carassius auratus) & transection & 6 & $\uparrow$ near transection & + & + & $?$ \\
\hline Black ghost knifefish $^{4,5}$ (A. albifrons) & amputation & - & $\uparrow$ near amputation & + & + & $?$ \\
\hline Brown ghost knifefish $^{6}$ (A. leptorhynchus) & amputation & 10 & $\uparrow$ near amputation & + & + & + \\
\hline
\end{tabular}

$+=$ Induction of new neurons, glia or microglia present; $-=$ no induction of new neurons, glia or microglia; $?=$ not measured; $\uparrow=$ cell proliferation upregulated.

${ }^{1}$ Dervan and Roberts [2003]; ${ }^{2}$ Reimer et al. [2008]; ${ }^{3}$ Takeda et al. [2008]; ${ }^{4}$ Anderson and Waxman [1985]; ${ }^{5}$ Anderson and Waxman [1983a] (based on in vivo cell counts and studies of in vitro explants); ${ }^{6}$ Sîrbulescu et al. [2009]; ${ }^{7}$ Schaefer and Zakon [1997]; ${ }^{8}$ present study.

charge amplitude, which may affect electrolocation and communication [Sîrbulescu et al., 2009]. After amputation in A. leptorhynchus, newly born cells in the caudal region of the spinal cord give rise to neurons, glia and ependymal cells [Anderson, 1986; Sîrbulescu et al., 2009]. These new cells contribute to the recovery of the electric organ discharge, thus restoring behavioral function. In contrast, spinal transection might induce the production of primarily nonneuronal cell types that are functionally linked to the degeneration and regeneration of descending axons [Schaefer and Zakon, 2007].

Adult neurogenesis in anamniotic vertebrates has attracted a great deal of interest over the past 30 years. It has been recognized that limited cellular proliferation is present throughout the intact adult rodent spinal cord. Under normal conditions, these cells continuously generate new astrocytes and oligodendrocytes, but not neurons [Horner et al., 2000]. In contrast, teleost fishes retain considerable proliferative potential to produce new neurons and glia [Reimer et al., 2008; Takeda et al., 2008; Sîrbulescu et al., 2009]. In A. leptorhynchus, cellular proliferation occurs either to replace damaged cells during the process of regeneration or as a consequence of indeterminate growth, adding new neurons and glia to the existing populations [cf. Schaefer and Zakon, 1997; Zupanc, 2006; Sîrbulescu et al., 2009]. Previous studies on the proliferation and differentiation of new cells in the spinal cord during and after tail amputation in apteronotid fishes revealed that these fishes can serve as a model for understanding the cellular processes of nervous system regeneration [Anderson and Waxman, 1985; Sîrbulescu et al., 2009]. Similarly, apteronotids show robust proliferative re- sponses to brain injury [Zupanc, 2001]. Our finding that a high-level spinal cord injury can induce a similarly robust proliferative response in the spinal cord far from the site of injury suggests that these animals also have a plastic and global regenerative response to spinal cord injury. Future studies examining the fate and connectivity of newly generated cells after spinal transection and the relationship between neurogenesis, regeneration of motor circuits and functional recovery in apteronotid fishes may provide insight into the mechanisms by which spinal motor systems can recover from traumatic spinal injury.

\section{Acknowledgments}

This work was supported by NIH MH 066960 (G.T.S.), the APS Porter Fellowship (A.R.A.) and the Center for the Integrative Study of Animal Behavior, and also through the use of equipment provided by the Indiana University Light Microscopy Imaging Center and by the Indiana METACyt Initiative of Indiana University, funded through a major grant from the Lilly Endowment, Inc.

\footnotetext{
References Anderson MJ, Choy CY, Waxman SG (1986): Self-organization of ependyma in regenerating teleost spinal cord: evidence from serial section reconstructions. J Embryol Exp Morphol 96:1-18.

-Anderson MJ, Waxman SG (1981): Morphology of regenerated spinal cord in Sternarchus albifrons. Cell Tissue Res 219:1-8.

Anderson MJ, Waxman SG (1983a): Caudal spinal cord of the teleost Sternarchus albifrons resembles regenerating cord. Anat Rec 205: 85-92.
} 
Anderson MJ, Waxman SG (1983b): Regeneration of spinal neurons in inframammalian vertebrates: morphological and developmental aspects. J Hirnforsch 24:371-398.

-Anderson MJ, Waxman SG (1985): Neurogenesis in adult vertebrate spinal cord in situ and in vitro: a new model system. Ann NY Acad Sci 457:213-233.

-Becker T, Wullimann MF, Becker CG, Bernhardt RR, Schachner M (1997): Axonal regrowth after spinal cord transection in adult zebrafish. J Comp Neurol 377:577-595.

Chernoff EA (1996): Spinal cord regeneration: a phenomenon unique to urodeles? Int J Dev Biol 40:823-831.

Coggeshall RE, Youngblood CS (1983): Recovery from spinal transection in fish: regrowth of axons past the transection. Neurosci Lett 38: 227-231.

Dervan AG, Roberts BL (2003): Reaction of spinal central canal cells to cord transection and their contribution to cord regeneration. J Comp Neurol 458:293-306.

-Gehrmann J, Banati RB (1995): Microglial turnover in the injured CNS: activated microglia undergo delayed DNA fragmentation following peripheral nerve injury. J Neuropathol Exp Neurol 54:680-688.

Gratzner HG (1982): Monoclonal antibody to 5-bromo- and 5-iododeoxyuridine: a new reagent for detection of DNA replication. Science 218:474-475.
Gundersen HJ (1986): Stereology of arbitrary particles. A review of unbiased number and size estimators and the presentation of some new ones, in memory of William R. Thompson. J Microsc 143:3-45.

Hanna GF, Nawar NN, Sharma SC (1998): Regeneration of ascending spinal axons in goldfish. Brain Res 791:235-245.

Horner PJ, Power AE, Kempermann G, Kuhn HG, Palmer TD, Winkler J, Thal LJ, Gage FH (2000): Proliferation and differentiation of progenitor cells throughout the intact adult rat spinal cord. J Neurosci 20:2218-2228.

Mallat M, Marin-Teva JL, Cheret C (2005): Phagocytosis in the developing CNS: more than clearing the corpses. Curr Opin Neurobiol 15:101-107.

Popovich PG, Guan Z, McGaughy V, Fisher L, Hickey WF, Basso DM (2002): The neuropathological and behavioral consequences of intraspinal microglial/macrophage activation. J Neuropathol Exp Neurol 61:623-633.

Reimer MM, Sorensen I, Kuscha V, Frank RE, Liu C, Becker CG, Becker T (2008): Motor neuron regeneration in adult zebrafish. J Neurosci 28:8510-8516.

Schaefer JE (1997): Physiological and anatomical plasticity of electromotor neurons in the electric fish, Apteronotus leptorhynchus; doctoral dissertation, University of Texas at Austin.

Schaefer JE, Zakon HH (1997): Neurogenesis of motoneurons in adult vertebrate CNS following deafferentiation. Abstr Soc Neurosci 23:317.
Sîrbulescu RF, Ilies I, Zupanc GK (2009): Structural and functional regeneration after spinal cord injury in the weakly electric teleost fish, Apteronotus leptorhynchus. J Comp Physiol A Neuroethol Sens Neural Behav Physiol 195:699-714.

Takeda A, Nakano M, Goris RC, Funakoshi K (2008): Adult neurogenesis with 5-HT expression in lesioned goldfish spinal cord. Neuroscience 151:1132-1141.

Vidal Pizarro I, Swain GP, Selzer ME (2004): Cell proliferation in the lamprey central nervous system. J Comp Neurol 469:298-310.

West MJ, Slomianka L, Gundersen HJ (1991): Unbiased stereological estimation of the total number of neurons in the subdivisions of the rat hippocampus using the optical fractionator. Anat Rec 231:482-497.

Yamada H, Miyake T, Kitamura T (1995): Regeneration of axons in transection of the carp spinal cord. Zoolog Sci 12:325-332.

Zupanc GK (2001): Adult neurogenesis and neuronal regeneration in the central nervous system of teleost fish. Brain Behav Evol 58: 250-275.

Zupanc GK (2006): Neurogenesis and neuronal regeneration in the adult fish brain. J Comp Physiol A Neuroethol Sens Neural Behav Physiol 192:649-670. 